\title{
Distribution extension of the yellow anaconda Eunectes notaeus Cope, 1862 (Squamata: Boidae) in the state of Rio Grande do Sul, Brazil
}

\author{
Guilherme S. Santos ${ }^{1}$, Thales de Lema ${ }^{2}$, Gisele R. Winck ${ }^{3}$, Sonia Z. Cechin ${ }^{4 *}$ and Ruben A. Boelter ${ }^{5}$ \\ 1 Anselmo Campos da Rosa 212. CEP 976070-000. São Borja, RS, Brasil. \\ 2 Southern Herpetology Office, Ave. Luiz Manoel Gonzaga, 100:1001. CEP 90470-280. Porto Alegre, RS, Brasil. \\ 3 Universidade do Estado do Rio de Janeiro, Instituto de Biologia Roberto de Alcântara Gomes, Departamento de Ecologia. Rua São Francisco \\ Xavier 524, Pavilhão Haroldo Lisboa, sala 220. CEP 20550-019. Rio de Janeiro, RJ, Brazil. \\ 4 Universidade Federal de Santa Maria, Departamento de Biologia, Laboratório de Herpetologia. Av. Roraima 1000, prédio 17, sala 1140. CEP \\ 97105-900. Santa Maria, RS, Brazil. \\ 5 Universidade Federal de Santa Maria, Centro de Ciências Naturais e Exatas, Programa de Pós-graduação em Biodiversidade Animal. Av. Roraima \\ 1000, prédio 17, sala 1140. CEP 97105-900. Santa Maria, RS, Brazil. \\ * Corresponding author. E-mail: soniacechin@gmail.com
}

\begin{abstract}
The yellow anaconda, Eunectes notaeus, was until recently considered as a species with accidental occurrence on southern Brazil, due to river floods from the Pantanal region on central Brazil. Here we provide monitoring records of a well-established population in the state of Rio Grande do Sul, and also discuss its distribution in the area.
\end{abstract}

Eunectes notaeus Cope, 1862 inhabits the Paraguay basin and is abundant at Pantanal of Mato Grosso, and also occurs in southern Brazil, Paraguay, and northeastern Argentina; thus, its distribution is apparently restricted to Río de La Plata basin (Figure 1). In Argentina, the species occurs in the provinces of Chaco, Corrientes, Entre Ríos, Formosa, Misiones, and Santa Fé (Giraudo and Scrocchi 2002; Giraudo 2003). In Uruguay, E. notaeus was found in Isla de Flores (Achaval and Olmos 1997), near the municipality of Montevideo. This species reaches up to four meters long (Waller et al. 2007), attaining sexual maturity with $0.83 \mathrm{~m}$ (Pizzato and Marques 2007).

At the state of Rio Grande do Sul, Brazil, Lema (1994) recorded the species for the municipality of Uruguaiana, on the basis of exposed skin at the Pontifícia Universidade Católica do Rio Grande do Sul. Di-Bernardo et al. (2004) rejected this record by assuming that the specimen was captured in Entre Ríos, Argentina. A specimen of $E$. notaeus was collected by Adolfo Stern in September 2009 at the Sanchuri River dam (29³4'54.62"S, 56 $\left.4550.95^{\prime \prime} \mathrm{W}\right)$ (Figure 2), located at the municipality of Uruguaiana. The specimen was confiscated by the State Environmental Police (PATRAM; Patrulha Ambiental do Estado do Rio Grande do Sul), and posteriorly sent to the IBAMA (Instituto Brasileiro do Meio Ambiente e dos Recursos Naturais Renováveis). This specimen measured about three meters of total length, and weighted $35 \mathrm{Kg}$. Later, an austral population of yellow anaconda, comprising seven individuals, was found in the municipality of São Borja, northwestern of the Rio Grande do Sul state, which we monitored during 2010 and 2011.

The area where the population of Eunectes notaeus was found (São Borja) comprises 3,371.05 $\mathrm{Km}^{2}$; the urban area extends by $71 \mathrm{Km}^{2}$, and the rural area $3,300.051 \mathrm{Km}^{2}$. It is located in the middle course of Uruguay River, nearby the Argentinian province of Misiones. Within the area of
São Borja are situated the basin of the Butui and Icamaquã rivers, tributaries of the Uruguay River; and the Puitã River and its tributaries, forming several swamplands named

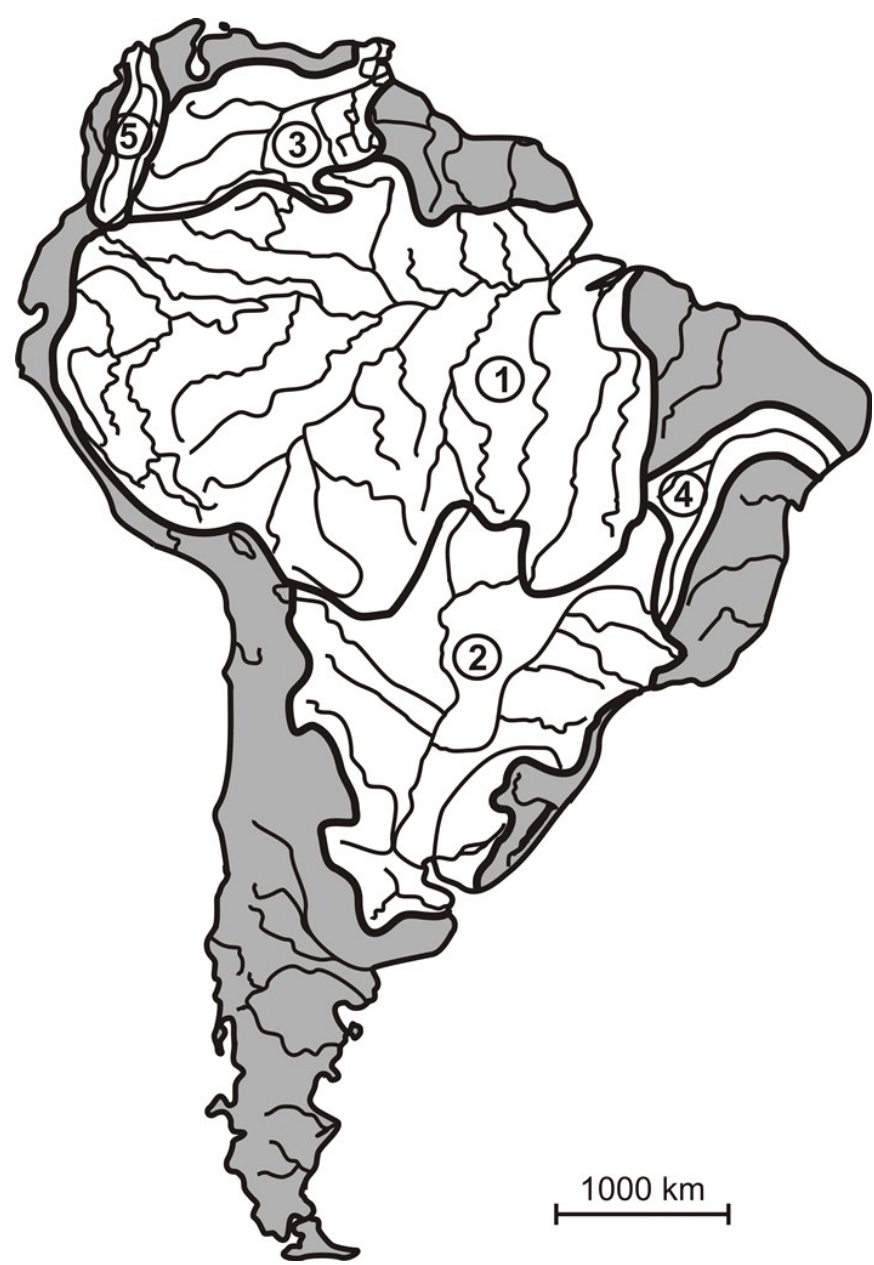

Figure 1. Main South American hydrographical basins (modified from Tundisi, 1994). 1 - Amazon basin; 2 - Río de La Plata basin; 3 - Orinoco basin; 4 - São Francisco basin; 5 - Magdalena basin. 
Butui, Caçaquã, Piriri, and Três Capões (Robaina et al. 2007). Large areas of the Campanha plateau and the Rio Ibicuí-Rio Negro depression are well preserved, mainly near the road axis of the municipalities of Bagé, Rosário do Sul, and Alegrete. The landscape is characterized by the presence of swamplands, grasslands, and watercourses, with riparian forests, typical of Pampa biome (see Pillar $e t$ al. 2009). The swamplands are located at the rivers plains of Butuí, Icamaquã, and Uruguay River and comprise excellent refuge to local biota, such as vertebrates and invertebrates with aquatic lifestyle. The better-conserved areas are located at the Icamaquã River, Iguariaça River, and Urucutai River (Robaina et al. 2007). The climate of the São Borja's region is classified as Subtropical temperate, with annual average temperature of $20^{\circ} \mathrm{C}$ (Maluf 2000). In January (summer) the median temperature is $26.9^{\circ} \mathrm{C}$ and $15.6^{\circ} \mathrm{C}$ in July (winter) (see Maluf 2000).

For monitoring E. notaeus individuals at the municipality of São Borja we made monthly visual and photographical observations, through active search limited by time (four hours). Searches were conducted at the rural zone from April 2009 to December 2010, mainly along riverbanks and rice cultures during the afternoon. Photographical records were employed for preservation of the specimens at their natural site, avoiding removal of individuals from the population. We believe there was no recount of individuals, due to different size at capture for all specimens. We also used photographs made by local residents.

We found individuals at different development stages (adults, young, and newborns) recorded in three localities situated at the Middle Uruguay River: Santa Luzia, São Ramão, and Rincão de Sant'Ana in Rio Grande do Sul state, Brazil; and at San Thomé, in the Corrientes province, Argentina. Two specimens were captured for photographic record in the locality Rincão de Sant'ana, and were released after the documentation, and no marking technique was employed. The first captured in October 04 2010 , measuring three meters of total length and $30 \mathrm{Kg}$ of weight; the second, in March 25 2011, with 2.4 m of total length and $28 \mathrm{Kg}$ of weight. In 2011, three specimens were captured: one was sent to IBAMA (Figure 3); the second

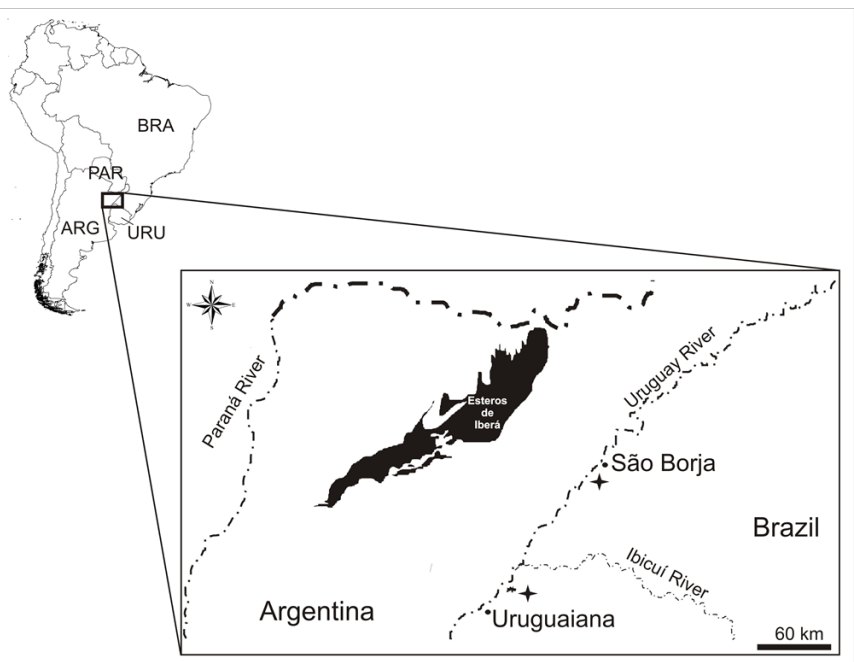

FIGURE 2. Map showing the localities where Eunectes notaeus was found in the region of the Brazilian state of Rio Grande do Sul, and neighboring areas (Paraguay, Argentina and Uruguay). In the detail is the region of São Borja municipality.

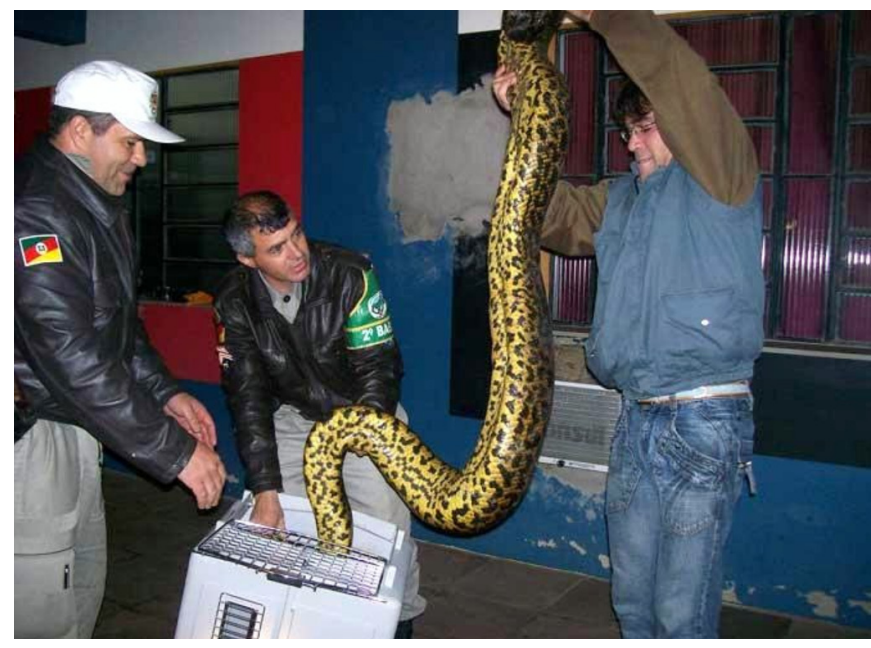

FIgURE 3. Eunectes notaeus individual found in São Borja, Rio Grande do Sul state, Brazil as it was being prepared by the Province's Environmental Police (PATRAM; Patrulha Ambiental do Estado do Rio Grande do Sul) to be transported to the Brazilian Institute of Environment and Renewable Natural Resources (IBAMA; Instituto Brasileiro do Meio Ambiente e dos Recursos Naturais Renováveis), at the municipality of Santa Maria, Rio Grande do Sul State, Brazil (http://zerohora.clicrbs.com.br/rs/ noticia/2009/09/sucuri-e-capturada-em-uruguaiana-2657653.html).

was sent to São Braz Conservationist Breeding (Criadouro Conservacionista São Braz) at municipality of Santa Maria (2941'36.68"S, 5349'16.80"W), state of Rio Grande do Sul; and the third was released in São Donato Biological Reserve (SDBR), between the municipalities of Itaqui and Maçambara (2908'01.11"S, 56¹8'30.51"W).

We observed Eunectes notaeus mainly in rice cultures at São Borja. Although we sighted more often the anacondas, we assumed the occurrence of only seven individuals in the area, due to their clear visual differences (e.g., size, coloration pattern). Because one of the individuals was juvenile, we propose a stable resident population probably dating from several generations considering the maturation size to E. notaeus (see Waller et al. 2007). Another species found in this area was Hydrodynastes gigas (Duméril, Bibron and Duméril, 1854), along the Río de La Plata basin, occurring at the same habitats of E. notaeus (Lema 1982) (including São Donato Biological Reserve; see Di-Bernardo et al. 2003). We believe that the occurrence of the yellow anaconda in Isla de Flores (Uruguay) (Achaval and Olmos 1997) is more likely accidental due river floods that carry many floating material (e.g., Eichornia spp.) with potential for transporting several species of amphibians and reptiles.

Due to its aggressive behavior, the conservation of $E$. notaeus at this study area is problematic. Many residents perceive the species as a threat to domestic animals and children. Also, E. notaeus is threatened by hunters, for meat and commerce of the skin. These records suggest the likely natural occurrence of this species along the entire Río de La Plata basin, until now uncertain mainly due to the lack of herpetological surveys in the area.

ACKNOWLEDGMENTS: This study received the authorization of IBAMA (process no 004/2011). We appreciated the contribution on fieldwork from Bruno Aranda, Lucas Bicca, and Olinto Dornelles. Many local residents from rural zones provided photography and vital information on specimens' location. Conselho Nacional de Desenvolvimento Científico e Tecnológico (CNPq) provided Postdoctoral Fellowship grant to GRW (process no 150855/2012-5), and financial support to SZC through the fund "Produtividade em Pesquisa". 


\section{Literature Cited}

Achaval, F. and A. Olmos. 2007. Anfibios y Reptiles del Uruguay. Montevideo: Facultad de Ciencias. 160 p.

Di-Bernardo, M., M. Borges-Martins and R.B. Oliveira. 2003. Répteis; p. 292-315 In C.S. Fontana, G.A. Bencke; Roberto E. Reis. (Org.). Livro vermelho da fauna ameaçada de extinção no Rio Grande do Sul. 1a ed. Porto Alegre: EDIPUCRS, 2003, v. 1, p. 1-632.

Di-Bernardo, M., M. Borges-Martins and R.B. Oliveira. 2004. Proposed delectation of eight species of snakes from the Brazilian state of Rio Grande do Sul herpetofauna. Comunicações do Museu de Ciências e Tecnologia da PUCRS, série Zoologia 17(1): 45-50.

Giraudo, A.R. and G.J. Scrocchi. 2002. Argentinean snakes: An annotated checklist. Smithsonian Herpetological Information Service 132: 1-53.

Giraudo, A.R. 2003. Serpientes de la Selva Paranaense y del Chaco Húmedo. Buenos Aires: LOLA. 289 p.

Lema, T. 1982. Fauna de Serpentes da província Pampeana e interrelações com as províncias limítrofes. Memórias do Instituto Butantan 46: 173-182.

Lema, T. 1994. Lista comentada dos répteis ocorrentes no Rio Grande do Sul, Brasil. Comunicações do Museu de Ciências e Tecnologia da PUCRS, série Zoologia 7: 41-150.

Maluf, J.R. 2000. Nova classificação climática do Estado do Rio Grande do Sul. Revista Brasileira de Agrometeorologia 8(1): 141-150.
Pillar, V.D., S.C. Müller, Z. Castilhos, A.V.A Jacques. 2009. Campos Sulinos: Conservação e Uso Sustentável da Biodiversidade. Brasília: Ministério do Meio Ambiente. 403 p.

Pizzato, L. and O.A.V. Marques. 2007. Reproductive ecology of Boine snakes, with emphasis on Brazilian species and comparison to pythons. South American Journal of Herpetology 2: 107-122.

Robaina, L.E.S., R. Trentin, D. Nardin and T. Bazzan. 2007. Atlas Geoambiental de São Borja. Santa Maria: Universidade Federal de Santa Maria, LAGEOLAM.

Tundisi, J.G. 1994. Tropical South America: present and perspectives; p. 353-424 In R. Margalef (ed.). Limnology Now: A paradigma of planetary problems. Amsterdam: Elsevier.

Waller T., P.A. Micucci and E. Alvarenga 2007. Conservation biology of the yellow anaconda (Eunectes notaeus) in northeastern Argentina, p. 140-162 In R.W. Henderson and E. Powell (ed.). Biology of the Boas and Pythons. Utah: Eagle Mountain Publishing, LC.

RECEIVED: November 2012

ACCEPTED: April 2013

Published Online: June 2013

EDITORIAL RESPONSIBILITY: Fernanda Werneck 